\title{
EKSISTENSI PEMBENTUKAN HUKUM OLEH HAKIM DALAM DINAMIKA POLITIK LEGISLASI DI INDONESIA
}

(The Existence of the Judge Made Laws in Dynamic Political Process of Legislation in Indonesia)

\author{
Budi Suhariyanto \\ Pusat Penelitian dan Pengembangan Hukum dan Peradilan MA-RI \\ Jl. Jend. Ahmad Yani Kav.58 Jakarta Pusat \\ Email: penelitihukumma@gmail.com \\ Naskah diterima: 30 September 2015; revisi: 25 November 2015; disetujui: 2 Desember 2015
}

\begin{abstract}
Abstrak
Secara normatif hakim Indonesia disebut sebagai Penegak hukum dan keadilan tidak sebatas corong undang-undang. Hakim wajib untuk menemukan, menggali dan membentuk hukum yang sesuai dengan nilai dan rasa keadilan masyarakat. Secara teoritis pembentukan hukum oleh Hakim pun diakui sebagai salah satu sumber hukum formil dalam sistem hukum Indonesia dan dapat diakomodasi oleh DPR (Positif Legislator) dalam pembaruan undang-undang. Tulisan ini bermaksud untuk meneliti masalah eksistensi pembentukan hukum oleh hakim dalam dinamika politik legislasi (baik yang bersifat positif legislasi sebagaimana diwenangi oleh DPR bersama Presiden maupun negatif legislator yang diperankan oleh putusan Mahkamah Konstitusi). Dengan menggunakan metode penelitian hukum normatif, diperoleh kesimpulan bahkan dalam konteks tertentu Hakim didorong untuk melakukan pembentukan hukum baru yang berfungsi sebagai $a$ tool of social engineering. Jika pembentukan hukum oleh Hakim diikuti secara konstan oleh Hakim lain maka dapat dijadikan sebagai sumber hukum formil dalam sistem hukum nasional (yurisprudensi).
\end{abstract}

Kata kunci: pembentukan hukum, hakim, politik legislasi

\section{Abstract}

Normatively in Indonesia, a judge is also known as the law and justice enforcement agency, not just decided cases based on written law. Judges are obliged to discover, explore and establish a legal system that suitable with local values and sense of justice. Theoretically Judge Decisions (known also as Jurisprudence) are also recognized as one of the source of formal lawsin the Indonesian legal system and can be accommodated by the Parliament (Positive Legislators) in the renewal of the law. This paper intends to examine the existence of the Judge made laws in dynamic-political process of legislation (whether positive legislation that is ruled by the House of Representatives and the President or negative legislator who are ruled by the Constitutional Court). Using a normative-legal research method, the conclusion even in the context of a particular judges are encouraged to establish anew legal construction that intended as a tool of social engineering. If the judge-made law is followed constantly by other judges, it can be used as a source of formal law in the national legal system (jurisprudence).

Keywords: establishment of law, judges, political process of legislation 


\section{A. Pendahuluan}

Pasal 5 ayat (1) Undang-Undang Nomor 48 Tahun 2009 tentang Kekuasaan Kehakiman (UU Kekuasaan Kehakiman) menegaskan bahwa "Hakim dan Hakim Konstitusi wajib menggali, mengikuti, dan memahami nilainilai hukum dan rasa keadilan yang hidup dalam masyarakat". Dalam penjelasannya, ketentuan ini dimaksudkan agar putusan hakim dan Hakim Konstitusi sesuai dengan hukum dan rasa keadilan masyarakat. Berdasarkan ketentuan yang demikian, hakim dituntut tidak hanya menegakkan hukum a quo (undangundang) semata, tetapi diwajibkan untuk menggali, mengikuti dan memahami nilai dan rasa keadilan masyarakat. Pada konteks ini UU Kekuasaan Kehakiman menegaskan bahwa hakim Indonesia bukanlah corong undangundang semata.

Melalui penegasan normatif yang demikian, secara legal formal terbuka ruang penemuan hukum oleh hakim. Kewenangan penemuan hukum dibuka untuk memberikan penjelasan terhadap ketentuan undang-undang yang belum jelas atau melengkapi pengaturan normatif yang tidak lengkap dan dimungkinkan untuk mengisi kekosongan hukum dari suatu undangundang. Ketidak-lengkapan, ketidak-jelasan dan kekosongan hukum ini merupakan konsekuensi dari sebuah realitas bahwa "teks" undangundang yang tidak selalu sempurna. Apalagi laju undang-undang yang statis dibandingkan dengan perkembangan masyarakat maka sifatnya sebatas moment opname sehingga harus di"kontekstualisasi"kan oleh hakim. Dalam hal ini hakim harus menafsirkan dan atau menggali kandungan norma yang terdapat di dalam undang-undang itu ${ }^{1}$ sehingga sesuai dengan perkembangan nilai dan rasa keadilan masyarakat.

Jika hakim tidak diberikan kewenangan untuk melakukan penemuan hukum maka kekosongan hukum yang terjadi akibat tidak sempurnanya undang-undang tersebut akan dapat berubah menjadi kekacauan. ${ }^{2}$ Oleh karenanya dalam melakukan usaha pencapaian terhadap nilainilai keadilan, hakim diberikan keleluasaan untuk melakukan penafsiran-penafsiran, penemuan-penemuan hukum bahkan menurut aliran progresif hakim dimungkinkan untuk melakukan penciptaan hukum jika kenyataan telah mengharuskan itu. ${ }^{3}$ Dalam konteks yang demikian, muncul pemikiran yang berpendapat bahwa adil tidaknya suatu undang-undang berada di pundak hakim. ${ }^{4}$ Sehingga hakim dimungkinkan melakukan pembentukan hukum yang selanjutnya dalam kondisi tertentu (diikuti secara konsisten oleh hakim lain) dapat dikategorikan sebagai salah satu sumber hukum formil.

Kedudukan hakim sebagai pembentuk hukum ini berbeda dengan pembentuk undang-undang (legislator). Hakim melalui kuasa pembentukan hukumnya dapat diikuti oleh hakim lainnya. Meskipun Indonesia tidak menganut precedent, namun pembentukan

Luhut M.P. Pangaribuan, Lay Judges \& Hakim Ad Hoc: Suatu Studi Teoritis mengenai Sistem PeradilanPidana Indonesia (Jakarta: Fakultas Hukum Pasca Sarjana Universitas Indonesia \& Papas Sinar Sisanti, 2009), hlm. 188.

2 Ansyahrul, Pemuliaan Peradilan: dari Dimensi Integritas Hakim, Pengawasan, dan Hukum Acara (Jakarta: Mahkamah Agung, 2011), hlm. 134

Darmoko Yuti Witanto \& Arya Putra Negara Kutawaringin, Diskresi Hakim: Sebuah Instrumen Menegakkan Keadilan Substantif dalam Perkara-Perkara Pidana. (Bandung: Alfabeta, 2013), hlm. 26.

4 Ahmad Kamil, Filsafat Kebebasan Hakim (Jakarta: Kencana Prenada Media, 2012), hlm. 211. 
hukum oleh hakim ini dalam praktek dapat dipedomani hakim lainnya di masa yang akan datang. Secara praktis pembentukan hukum oleh hakim ini juga dapat diikuti oleh penegak hukum dan secara akademis diterima oleh akademisi hukum sebagai salah satu khasanah pengembangan ilmu hukum. Meskipun demikian, hasil pembentukan hukum yang dilakukan oleh hakim ini, dalam konteks politik legislasi belum tentu dapat diterima secara otomatis dalam bentuk pembaruan undangundang atau pengaturan norma yang baru.

Dewan Perwakilan Rakyat (selain Presiden) sebagai pemegang kuasa dan pelaksana fungsi legislasi merupakan sebuah institusi politik. Dalam optik politik, keberadaan pembaruan hukum (undang-undang) yang dibidangi oleh DPR ini bersifat sangat dinamis. Suatu hukum bisa dirupakan dalam undang-undang, harus melalui sebuah konsensus diantara anggotanya. Secara fungsional, berbagai pertimbangan politis, ekonomi dan sosiologis dari konfigurasi konsensus tersebut berpengaruh terhadap konstelasi hukum yang akan dibuat. Dalam konteks ini, dinamika politik legislasi tidak dapat dihindarkan pengaruhnya terhadap hukum. Karenanya eksistensi pembentukan hukum oleh hakim itu tidak selalu berpengaruh secara positif terhadap dinamika politik legislasi. Meskipun demikian, tidak sedikit yang menginspirasi dan diakomodir sebagai revisi undang-undang oleh para legislator, semisal penerapan sifat melawan hukum materiil dalam Pasal 2 UndangUndang No. 31 Tahun 1999 Jo. Undang-Undang 20 Tahun 2001 tentang Pemberantasan Tindak Pidana Korupsi yang notabene mengakomodasi Yurisprudensi Mahkamah Agung.
Selain itu dihubungkan dengan kewenangan Mahkamah Konstitusi dalam judicial review (yang notabene berfungsi sebagai negatif legislator), pembentukan hukum oleh hakim pada Mahkamah Agung dan badan peradilan di bawahnya juga berhubungan secara dinamis. Politik legislasi (dalam membatalkan suatu norma undang-undang yang dibuat oleh DPR bersama Presiden sebagai representasi fungsinya sebagai the guardian of constitution dan the final interpreter of the costitution serta the guardian of the democratic process dan the protector of human right $)^{5}$ di Mahkamah Konstitusi tidak sepenuhnya statis dilaksanakan atau diikuti oleh Hakim Mahkamah Agung dan badan peradilan di bawahnya. Padahal putusan Mahkamah Konstitusi tersebut mempunyai daya ikat kepada seluruh orang dan organ negara (erga omnes) termasuk hakim pada Mahkamah Agung dan badan peradilan di bawahnya. Dalam praktik ditemukan beberapa kasus pembentukan hukum oleh hakim pada Mahkamah Agung dan badan peradilan dibawahnya tidak selalu berkorelasi secara positif dan sinergis dengan produk "hukum" yang ditetapkan oleh pemegang kuasa negatif legislator. Misalnya meskipun sudah diputuskan oleh Mahkamah Konstitusi bahwa penerapan sifat melawan hukum materiil dalam frase penjelasan pasal 2 Undang-Undang No. 31 Tahun 1999 Jo. Undang-Undang 20 Tahun 2001 tentang Pemberantasan Tindak Pidana Korupsi adalah tidak mengikat, namun Mahkamah Agung dalam sebagian putusannya tidak mengindahkannya dengan pertimbangan dasar mempedomani yurisprudensi.

Malik, “Telaah Makna Hukum Putusan Mahkamah Konstitusi yang Final dan Mengikat”, Jurnal Konstitusi, Volume 6 Nomor 1 (2009), hlm. 93. 
Berdasarkan latar belakang di atas maka menarik untuk diteliti masalah eksistensi pembentukan hukum oleh hakim dalam dinamika politik legislasi (baik yang bersifat positif legislasi sebagaimana diwenangi oleh DPR bersama Presiden maupun negatif legislator yang diperankan oleh putusan Mahkamah Konstitusi). Dalam tulisan ini dapat diuraikan dalam beberapa pokok permasalahan (i) bagaimana eksistensi pembentukan hukum oleh hakim dalam sistem hukum Indonesia? (ii) bagaimana eksistensi pembentukan hukum oleh hakim dalam dinamika politik legislasi?

\section{B. Metode Penelitian}

Metode penelitian untuk mengkaji masalah eksistensi pembentukan hukum oleh hakim dalam dinamika politik legislasi di Indonesia ini menggunakan metode penelitian hukum normatif. Pada penelitian hukum normatif ini, digunakan beberapa pendekatan masalah diantaranya yaitu pendekatan perundangundangan (Statute Approach) dan pendekatan kasus (Case Approach). Pendekatan perundangundangan digunakan untuk mengkaji masalah secara normatif baik dari perspektif ius constitutum maupun ius constituendum. Sedangkan pendekatan kasus digunakan untuk mengkaji masalah dari segi praktek peradilan yang berkembang dalam merespon dan mengaktualisasikan isu hukum secara in concreto.

Sumber data yang digunakan dalam penelitian ini berasal dari data sekunder yang terdiri atas bahan hukum primer berupa peraturan perundang-undangan dan putusan pengadilan serta bahan hukum sekunder berupa literatur dan hasil penelitian. Data sekunder diperoleh dan dikumpulkan melalui metode sistematis guna memudahkan analisis terhadap pokok-pokok permasalahan. Bahanbahan tersebut dikumpulkan dan diklasifikasi sesuai dengan permasalahannya, asas-asas, argumentasi, implementasi yang ditempuh, alternatif pemecahannya dan lain sebagainya. Selanjutnya untuk mendapatkan kesimpulan atas permasalahan yang dibahas digunakan sebuah analisis yang bersifat yuridis kualitatif.

Adapun kepustakaan yang dominan dipergunakan adalah kepustakaan dalam bidang hukum khususnya mengenai pembentukan hukum oleh hakim dalam dinamika politik legislasi di Indonesia. Lokasi penelitian kepustakaan dilakukan di beberapa tempat antara lain di Perpustakaan Balitbangdiklat Kumdil Mahkamah Agung RI, Perpustakaan Mahkamah Agung RI, Perpustakan Nasional Republik Indonesia, Perpustakaan Universitas Indonesia serta perpustakaan lain yang menyediakan data sekunder yang sesuai dan diperlukan dalam penelitian ini.

\section{Pembahasan}

\section{Eksistensi Pembentukan Hukum oleh Hakim dalam Sistem Hukum Indonesia}

Pembentukan hukum menurut Sudikno Mertokusumo adalah apa yang dimaksud dengan penemuan hukum lazimnya adalah proses pembentukan hukum oleh hakim, atau aparat hukum lainnya yang ditugaskan untuk penerapan peraturan hukum umum pada peristiwa konkret. ${ }^{6}$ Berdasarkan pendapat yang demikian, Sudikno Mertokusumo menegaskan bahwa tidak hanya hakim yang memiliki

6 Sudikno Mertokusumo, Penemuan Hukum: Sebuah Pengantar (Yogyakarta: Cahaya Atma Pustaka, 2014), hlm. 49 
kewenangan membentuk hukum, aparat hukum atau pejabat lainnya pun dalam menerapkan peraturan hukum dapat dikategori sebagai pembentuk hukum.

Berkaitan dengan hal tersebut, W Van Gerven memperkenalkan adanya tiga jenis model pembentukan hukum yaitu: (1). Pembentukan hukum preventif adalah yang dilakukan oleh pakar hukum perusahaan, notariat dan pakar hukum pemerintahan; (2). Pembentukan hukum reflektif yang dilakukan oleh ilmuwan hukum dan Guru Besar hukum; (3). Pembentukan hukum conflichtif adalah yang dilakukan oleh praktisi hukum seperti halnya, hakim, jaksa dan advokat. ${ }^{7}$ Sementara itu J.J Bruggink mengemukakan bahwa di dalam masyarakat yang memiliki kewenangan pembentukan hukum, termasuk di dalamnya adalah Badan Pembentuk Undang-Undang (legislatif), Badan Kehakiman (yudikatif), dan Badan Pemerintahan (eksekutif). ${ }^{8}$

Kepada para pengemban kewenangan hukum tersebut diberikan kewenangan (tugas) untuk berdasarkan kesadaran hukum mereka memberikan suatu bentuk yang positif berkepastian hukum. Tanpa mempersoalkan pendapat pertama dan yang kedua di atas, namun yang pasti dapat disimak bahwa ketiga jenis model pembentukan hukum dilihat dari segi sumbernya tersebut, maka yang menjadi sasaran perhatian adalah pembentukan hukum conflichtif, yang oleh pendapat J. J Bruggink disebutnya badan kekuasaan kehakiman atau yudikatif, yakni antara lain adalah pembentukan hukum oleh hakim. ${ }^{9}$ Pembentukan hukum oleh hakim inilah yang memegang peran penting dalam konteks penegakan hukum, karena dalam setiap putusannya terkandung penafsiran terhadap undang-undang.

Memang hakim bukan satu-satunya yang menafsirkan undang-undang, Tetapi menurut Bagir Manan harus diakui peranan hakim sangat penting. Mengapa? Pertama, hakim yang mewujudkan hukum (dalam arti) konkrit. Melalui putusan hakim, ketentuan undang-undang (hukum) yang abstrak menjadi suatu kenyataan. Kedua, hakim bukan hanya menyatakan (menetapkan) hukum bagi yang berperkara (menciptakan hukum bagi pihakpihak), tetapi dapat juga menciptakan hukum yang berlaku umum. Ketiga, hakim menjamin aktualisasi hukum, termasuk mengarahkan perkembangan hukum. ${ }^{10}$ Atas peran yang demikian, kedudukan hakim sangat strategis dalam sebuah negara hukum.

Pada dasarnya dalam suatu negara hukum (rechtstaat) seperti Indonesia, hakim dalam menegakkan hukum dan keadilan merupakan salah satu sendi dasar yang pokok dan utama. ${ }^{11}$ Melalui representasi hakim yang demikian, pemaknaan negara hukum ini tidak diartikan sebagai supremasi undang-undang, tetapi yang dihendaki oleh konstitusi adalah supremasi hukum. Dalam konteks ini sesuai dengan

Nurul Qamar, Percikan Pemikiran Tentang Hukum (Makassar: Pustaka Refleksi, 2011), hlm. 43-44.

Ibid, hlm. 44 .

Ibid.

10 Bagir Manan, Penafsiran sebagai Bentuk Penemuan Hukum, dalam Idris, dkk. (Ed), Penemuan Hukum Nasional dan Internasional (dalam rangka Purna Bakti Prof. Dr. Yudha Bhakti, SH., MH). (Bandung: Fikahati Aneska, 2012), hlm. 84.

11 Lilik Mulyadi, Hukum Acara Pidana Indonesia: Suatu Tinjauan Khusus terhadap Surat Dakwaan, Eksepsi dan Putusan Peradilan (Bandung: Citra Aditya Bakti, 2012), hlm. 54. 
pasal 24 Undang-Undang Dasar (UUD) 1945 menyatakan bahwa "Kekuasaan Kehakiman merupakan kekuasaan yang merdeka untuk menyelenggarakan peradilan guna menegakkan hukum dan keadilan". Termasuk dalam kategori kemerdekaan yang dimaksudkan adalah kemerdekaan dalam hal memaknai nilai-nilai hukum dan rasa keadilan, sehingga hakim Indonesia tidak mutlak terikat dengan undang-undang (bukan corong undang-undang) sebagaimana sistem hukum Eropa-kontinental.

Meskipun sistem hukum Indonesia dalam beberapa bagian dipengaruhi sistem hukum Eropa-kontinental tetapi pada bagian lain ternyata juga terdapat pengaruh sistem common law. Maka dari itu dalam memposisikan hakim, berbeda dengan kedua sistem tersebut secara parsial. Pada satu sisi tidak serta merta mengikuti sistem hukum Eropa-kontinental yang memandang bahwa hukum itu didasarkan pada prinsip kodifikasi dan kepastian dalam konteks ini hukum itu disamakan dengan undang-undang sehingga hakim seakan seperti corong undang-undang. Sementara itu di sisi lain juga tidak mutlak mengikuti sistem hukum common law yang menetapkan bahwa kaidah hukum didasarkan pada putusan hakim yang disertai precedent dan menempatkan hukum yang hidup (living law) menjadi rujukan dalam perumusan hukumnya. Pada kenyataannya lembaga peradilan Indonesia menyerap kedua sistem tersebut dan memadukannya dengan pendekatan urgensi peristiwa hukum kongkrit yang notabene di satu pihak bergantung pada pilihan hukum atau politik hukum lembaga pembentuk undang-undang tetapi di pihak lain tidak membelenggu hakim atas acuan dasar keadilan dan kemanfaatan. ${ }^{12}$

Kedudukan hakim Indonesia yang demikian tercermin secara normatif dalam pasal 5 ayat (1) Undang-Undang No. 48 Tahun 2009 tentang Kekuasaan Kehakiman menegaskan bahwa "Hakim dan Hakim Konstitusi wajib menggali, mengikuti, dan memahami nilai-nilai hukum dan rasa keadilan yang hidup dalam masyarakat". Ketentuan ini harus diartikan sebagai sebuah kewajiban bagi hakim karena hakim merupakan perumus dan penggali nilainilai hukum yang hidup dikalangan rakyat. ${ }^{13}$ Sebagaimana diketahui bahwa tidak ada hukum atau perundang-undangan yang sangat lengkap. Peraturan hukum yang tidak jelas harus dijelaskan, yang tidak lengkap harus dilengkapi dengan jalan menemukan hukumnya agar aturan hukumnya dapat diterapkan terhadap peristiwanya. ${ }^{14}$

Selain itu pasal 10 ayat (1) UndangUndang No. 48 Tahun 2009 tentang Kekuasaan Kehakiman menegaskan bahwa "Pengadilan dilarang menolak untuk memeriksa, mengadili, dan memutus suatu perkara yang diajukan dengan dalih bahwa hukum tidak ada atau kurang jelas, melainkan wajib untuk memeriksa dan mengadilinya". Ketentuan ini didasarkan atas asas ius curia novit. Apabila hakim tidak menemukan hukum tertulis atausuatuperaturan perundang-undangan belum jelas mengaturnya, hakim harus bertindak berdasarkan insiatifnya

12 Zainal Arifin Hoesein, Kekuasaan Kehakiman di Indonesia (Yogyakarta: Imperium, 2013), hlm. 171-172.

13 Lilik Mulyadi, Bunga Rampai Hukum Pidana: Perspektif Teoritis dan Praktik. (Bandung, Alumni. 2012), hlm. 378379.

14 Bambang Sutiyoso, Metode Penemuan Hukum: Upaya Mewujudkan Hukum yang Pasti dan Berkeadilan (Yogyakarta: UIT Press, 2012), hlm. 50-51. 
sendiri menyelesaikan perkara tersebut. Hakim harus berperan menentukan apa yang merupakan hukum, sekalipun peraturan perundang-undangan belum jelas. ${ }^{15}$ Dalam konteks ini, hakim harus aktif berperan untuk menemukan hukum dan membentuk hukum baru serta mengembangkan hukum. ${ }^{16}$

Jika hakim tidak aktif dalam menemukan dan membentuk hukum hingga menolak untuk menyelesaikan suatu perkara dengan alasan bahwa peraturan perundang-undangan yang bersangkutan tidak menyebutkan, tidak jelas atau tidak lengkap, maka ia dapat dituntut untuk dihukum karena menolak mengadili, sebagaimana diatur dalam pasal 22 A.B (Algemen Bepalingen van wetgeving voor Indonesia). ${ }^{17}$ Olehnya hakim diberikan hak dan kewenangan untuk menciptakan hukum (Judge Made Law), terutama terhadap kasus-kasus yang sama sekali belum ada hukumnya, tetapi telah masuk di pengadilan. Bahkan hakim juga mempunyai kewenangan untuk menyimpangi ketentuan-ketentuan hukum tertulis yang telah ada dan telah usang ketinggalan zaman sehingga tidak lagi mampu memenuhi rasa keadilan masyarakat (Contra Legem). ${ }^{18}$

Bilamana keputusan hakim yang berisikan suatu pertimbangan-pertimbangan hukum sendiri berdasarkan kewenangan yang diberikan oleh pasal 22 A.B ini kemudian menjadi dasar putusan hakim lainnya di kemudian hari untuk mengadili perkara yang memiliki unsur-unsur yang sama, selanjutnya putusan hakim tersebut menjadi sumber hukum di pengadilan. Putusan hakim yang demikian itu disebut "Hukum Yurisprudensi", 19 yang akan menjadi hukum objektif yaitu hukum objektif yang didasarkan kepada kebiasaan yang selalu diikuti, yang menjadi keyakinan hukum umum dan berlaku sebagai hukum positif. Dengan demikian, dapat menjadi pengaruh timbal balik antara hakim dan pembentuk undang-undang, yaitu suatu pembentukan hukum melalui putusan pengadilan, yang telah menjadi yurisprudensi tetap, yang dapat digunakan atau dapat menjadi umpan balik dalam proses pembentukan hukum oleh pembuat undang-undang. ${ }^{20}$

Dihubungkan dengan penjelasan di atas maka cukup relevan pendapat Bagir Manan yang menyatakan bahwa bagi hakim, ada tiga hal yang dihadapi. Pertama, hakim wajib memutus menurut hukum. Setiap putusan harus didasarkan pada kaidah hukum tertentu yang telah ada pada saat peristiwa hukum terjadi (bukan saat akan memutus). Kedua, hakim dilarang menolak memutus atas alasan

15 Lilik Mulyadi, Bunga Rampai ..Op Cit, hlm. 378.

16 Atja Sonjaya, Peranan Pengadilan dalam Penemuan Hukum, dalam Idris, dkk. (Ed), Penemuan Hukum Nasional dan Internasional (dalam rangka Purna Bakti Prof. Dr. Yudha Bhakti, SH., MH). (Bandung: Fikahati Aneska, 2012), hlm. 68.

17 Pemerintah Hindia Belanda, pada tanggal 30 April 1847 mengeluarkan Algemen Bepalingen van wetgeving voor Indonesia, disingkat A.B (ketentuan-ketentuan umum tentang Peraturan perundang-undangan untuk Indonesia) dalam Staatsblad 1847 No. 23 yang sampai saat ini masih berlaku berdasarkan ketentuan pasal II Aturan Peralihan Undang-Undang Dasar 1945 yang menyatakan, "segala badan negara dan peraturan yang ada masih langsung berlaku selama belum diadakan yang baru menurut Undang-Undang-Dasar ini." Lihat dalam Ahmad Kamil dan M. Fauzan, Kaidah-Kaidah Hukum Yurisprudensi, (Jakarta: Kencana, 2008), hlm. 8-9.

18 Ibid, hlm. 9.

19 Ibid, hlm. 9.

20 Pontang Moerad, Pembentukan Hukum melalui Putusan Pengadilan dalam Perkara Pidana, (Bandung: Alumni, 2005), hlm. 85. 
tidak tersedia kaidah hukum atau aturan yang ada tidak jelas. Ketiga, hakim wajib memutus dengan cepat, mengingat ungkapan yang mengatakan "justice delayed, is justice denied". Untuk mengatasi masalah-masalah ini, tidak mungkin semata-mata diandalkan kepada pembentuk kaidah hukum yang lamban (butuh waktu). Apalagi di Indonesia. DPR yang semestinya bekerja penuh (harian) membentuk undang-undang, lebih banyak bekerja untuk urusan lain. Suatu anomali dari begitu banyak anomali penyelenggaraan negara dan pemerintahan kita. ${ }^{21}$

\section{Eksistensi Pembentukan Hukum oleh Hakim dalam Dinamika Politik Legislasi}

Meskipun secara normatif, pembentukan hukum oleh hakim didudukkan sebagai pengisi atau penjelas hukum (undang-undang) dalam arti yang kongkrit. Namun keberadaannya tidak sepenuhnya berada dalam posisi "mapan" untuk dijadikan bahan baku pembaruan hukum (undang-undang). Karena di Indonesia pembaruan hukum acap kali masih saja diperbincangkan dalam konsepnya yang terbatas sebagai legal reform (pembaruan undangundang atau pembaruan sistem perundangundangan belaka). Dalam konsepsinya seperti ini, pembaruan hukum akan berlangsung sebagai aktivitas legislatif yang umumnya hanya sempat melibatkan pemikiran-pemikiran kaum politisi atau pemikiran para elit profesional yang memiliki akses lobi. 2

Tidak semata-mata konstruksi keterwakilan rakyat secara fundamental dapat sinergis dengan yang dikendaki oleh negara (elit perumus kebijakan penyelenggara negara). Sebagaimana teori legisprudence kritis yang menempatkan posisi negara dan masyarakat dalam dinamika politik yang tidak saling berbenturan, kompromistik, dan bisa saling berbagi peran dalam proses pembentukan hukum. Rubin (ahli hukum Amerika Serikat), ketika menganalisis proses legislasi dalam pembentukan "Truth in Lending Act" (UndangUndang Kebenaran dalam Pemberian Pinjaman) di Amerika Serikat, menggunakan bahasa teori pluralisme dan/atau teori pilihan masyarakat. Teori yang menyatakan adanya tawar-menawar dari kekuatan relatif dari kelompok-kelompok yang berkepentingan dengan sekelompok legislator yang memiliki jumlah suara besar di parlemen. ${ }^{23}$ Dalam konteks ini dinamika politik legislasi secara internal tidak dapat dihindarkan.

Secara fungsional dinamika politik legislasi ini juga tidak imun (kebal) dari berbagai intervensi ekstra legislatif. Sebagaimana dikritisi oleh teori legisprudence kritis bahwa tafsir dan proses pembentukan hukum melalui kelembagaan negara, dan mengabsahkannya sebagai satu-satunya proses politik perundangundangan. Teori ini meyakini bahwa proses "via negara" tidak semata-mata dibawa dan dikawal oleh pemegang kekuasaan dalam badan legislatif, tetapi banyak dipengaruhi oleh pengetahuan, peran, kepentingan, dan tafsir-tafsir yang mengerubuti badan legislatif ataupun aktor-aktornya, untuk dipilahpilah mana yang didorong "via negara" dan mana yang tidak. Artinya, pembentukan

Bagir Manan, Penafsiran Sebagai Bentuk Penemuan Hukum, dalam Idris dkk (Ed), Op Cit, hlm. 79.

22 Yesmil Anwar dan Adang, Pembaruan Hukum Pidana, (Jakarta: Grassindo, 2008), hlm.4-5..

23 Juhaya S. Praja, Teori Hukum dan Aplikasinya, (Bandung:Pustaka Setia, 2011), hlm. 143. 
hukum tidak lagi bergantung di bawah doktrin pemisahan kekuasaan, sebagaimana digambarkan Montesquieu, serta tidak lagi bisa mengklaim politik perundang-undangan sebagai satu proses prosedural mekanistik. ${ }^{24}$ Oleh karenanya proses politik dalam dinamisasi legal reform ini merupakan sebuah keniscayaan dan terkonfigurasi dalam politik hukum dari penyelenggara kekuasaan negara.

Secara struktural jika kita melihat legal reform ini dari kajian semiotika hukum, pembaruan itu tidaklah akan bisa mengikuti keterlibatan khalayak ramai yang awam. Berada dalam satu lingkungan yang disyaratkan oleh pengalaman budaya dan pengalaman berbahasa yang amat sangat berbeda, khalayak ramai ini akan sulit untuk memasuki suatu wacana yang dikuasai oleh apa yang disebut dengan linguistic domination system para elit politisasi dan elit profesional yang dengan itu mampu mendominasi percaturan hukum formal. Di samping itu, legal reform akan lebih gampang merespon kepentingan mereka yang mapan untuk berkuasa daripada kepekaan pada kepentingan mereka yang berkedudukan marjinal dan mempunyai keadaan hidup yang sangat rawan. ${ }^{25}$ Dalam konteks ini rawan sekali terjadi monopoli dan kapitalisme hukum.

Selain itu secara kultural, dinamisasi politik legislasi dalam konteks legal reform tidak selesai dan berhenti sebatas diundangkannya produk hukum (undang-undang) yang dihasilkan. Tetapi lebih daripada itu pasca diterbitkannya hasil konsensus legislator tersebut, berpeluang menjadi aktor kriminogen. Sebagaimana dijelaskan oleh Satjipto Rahardjo bahwa hukum itu juga bisa bersifat kriminogen, artinya menjadi sumber bagi kejahatan. Kelalaian atau ketidakseksamaan mengatur masyarakat yang begitu majemuk, seperti Indonesia ini, sangat berpotensi menimbulkan pengaturan yang kriminogen tersebut. Sekalipun legislatif "bermaksud baik", tetapi karena kurang cermat memahami keaneka-ragaman sosial dan budaya Indonesia, maka produk yang dihasilkannya bisa menimbulkan persoalan besar pada waktu diterapkan di salah satu bagian dari negeri ini. ${ }^{26}$

Untuk menutupi celah kesenjangan dan keberpihakan dalam proses politik legislasi yang menghasilkan kontra produktif dengan kepentingan dan kebutuhan rakyat atau masyarakat terhadap hukum yang aktual dan kongkret, maka hakim harus mengambil peranan. Melalui penemuan hukum, hakim dapat menghindarkan rakyat dari ketertindasan pelaksanaan produk hukum (undang-undang) yang tidak adil. Bahkan melalui pembentukan hukum baru, hakim juga berperan secara strategis melindungi budaya masyarakat dari efek kriminogen yang ditimbulkan oleh praktek politik legislasi yang tidak "membumi" secara kultural. Dalam konteks inilah law reform yang dikendalikan oleh hakim mendapatkan wilayah perjuangan yang vital.

Berkaitan dengan kondisi dinamika politik legislasi di atas, pembentukan hukum oleh hakim harus dibuka peran dan eksistensinya guna menjembatani antara teks normatif hasil produk politik legislasi yang notabene bersifat abstrak dan statis, dikontekstualisasikan

24 Ibid.

25 Yesmil Anwar dan Adang, Op Cit, hlm. 5.

26 Satjipto Rahardjo, Penegakan Hukum Progresif(Jakarta: Kompas, 2010), hlm. 63-64. 
dengan realitas yang ada dan bersifat dinamis. Oliver Wendel Homes mengatakan bahwa hukum bukanlah suatu sistem teks normatif yang tertutup. Menjaga kemurnian hukum dengan menutup diri dari pengaruh kontekskonteksnya adalah suatu upaya yang tidak hanya sia-sia akan tetapi juga tidak realistis. Seorang hakim (setiap hakim) yang bertanggungjawab memformulasikan hukum lewat keputusankeputusannya, harus selalu berdasarkan pada keyakinan yang benar, akan kebenaran pernyataan bahwa hukum bukanlah sesuatu "omnipresent in the sky" melainkan sesuatu yang senantiasa hadir dalam situasi-situasi kongkrit "to meet the social need". ${ }^{27}$

Setelah teks tersebut dikontekskan dalam situasi kongkrit, maka persoalan ketertinggalannya dengan arus perkembangan masyarakat semakin nyata, karenanya hakim harus menyesuaikannya. Demikian pula jika terjadi kejumudan hukum dengan realitas yang ada, atas dorongan moralitas dan itikad baik untuk menghadirkan konstruksi keadilan yang visioner (substantif justice) maka "hukum" dari putusan hakim dapat berperan membukaloronglorong perubahan sosial (stimulus perubahan paradigma nilai yang mewujud pada kebaruan perilaku dan kebiasaan). Implikasinya terbuka peluang untuk menambah daya guna putusan hakim menjadi a tool of social engineering. Sebagaimana dikehendaki oleh Roscoe Pound bahwa fungsi social engineering (rekayasa sosial) dari hukum maupun putusan hakim pada setiap masyarakat (kecuali masyarakat totaliter), ditentukan dan dibatasi oleh kebutuhan untuk menyeimbangkan antara stabilitas hukum dan kepastian terhadap perkembangan hukum sebagai alat evolusi sosial. Dalam konteks ini fungsi kreatif dari hakim yang akan berkembang dalam sistem-sistem hukum kebijaksanaan. Karenanya menjadikan perkembangan hukum oleh pengadilan yang kreatif bertambah penting. ${ }^{28}$

Sebagai contoh adalah pertimbangan hukum dari Putusan Nomor 55/PK/Pid/1996 yang secara kreatif dan progresif memainkan fungsi social engineering. Jika sebelumnya negara melalui legislasi mengatur bahwa Korban baik dalam arti individu maupun masyarakat (a quo kepentingan umum) serta kepentingan negara tidak memiliki hak untuk mengajukan upaya hukum Peninjauan Kembali sebagaimana diatur secara eksplisit dalam pasal 263 KUHAP. Namun seiring dengan perkembangan ilmu viktimologi dan hak asasi manusia, terlihat nyata bahwa hukum produk legislasi tidak memberikan keadilan atau keberpihakan pada hak-hak Korban yang asasi dalam sistem peradilan pidana. Karenanya hakim berkehendak mengubah dan menyempurnakannya sesuai dengan rasa keadilan masyarakat yaitu dengan menyeimbangkan hak individu Pelaku di satu sisi dengan Korban di sisi yang lain.

Setelah adanya putusan ini, penegasan tentang artinya perlindungan hukum terhadap Korban dalam sistem peradilan pidana mendapatkan tempat dalam diskursus wacana keadilan publik hingga membentuk paradigma baru tentang urgensi hak-hak Korban. Implikasinya pembentukan hukum oleh legislator menyambut "bola" keyakinan umum tersebut dalam bentuk pembaruan hukum

Yesmil Anwar dan Adang, Op Cit, hlm. 7-8.

28 Achmad Ali, Menguak Tabir Hukum (Bogor: Ghalia Indonesia, 2011), hlm. 159. 
baru yang responsif terhadap hak-hak Korban, baik yang bersifat eksplisit maupun implisit dalam norma peraturan perundang-undangan. Diantara eksistensi pembaruan atau rekonstruksi kedudukan dan hak-hak Korban tersebut berwujud Undang-Undang Perlindungan Saksi dan Korban berikut secara institusional dibentuk Lembaga khusus Perlindungan Saksi dan Korban (LPSK). Demikian besar dampak dan hubungan positif atas eksistensi pembentukan hukum oleh hakim yang berfungsi a tool of social engineering, hingga bisa menggerakkan diskursus publik dan membentuk keyakinan umum serta menginspirasi pembaruan hukum dalam politik legislasi. Atas peran dan hasil dari pembentukan hakim yang demikian maka dapat dikatakan bahwa hakim pun sejatinya adalah salah satu aktor pembaru hukum dan pihak yang juga berpengaruh dalam dinamika politik legislasi di negeri ini.

Meskipun demikian tidak semua putusan hakim itu mengandung fungsi a tool of social engineering yang dapat berpengaruh secara positif dalam politik legislasi. Menurut Achmad Ali, jika dikaji semua putusan hakim yang telah mempunyai kekuatan yang pasti (kracht van gewijsde) dan yang merupakan hasil produk penemuan hukum hakim, maka kita dapat membedakan sebagai berikut: 29

1. Penemuan hukum oleh hakim yang hanya sekedar menjadi jalan bagi hakim untuk menerapkan hukum dalam kasus kongkrit, tetapi sama sakali tidak mempunyai efek terhadap penyesuaian hukum pada perubahan masyarakat maupun efek melakukan perekayasaan masyarakat. Jenis putusan semacam ini yang terbanyak kita temukan.

2. Penemuan hukum oleh hakim yang merupakan karya hakim untuk menyesuaikan hukum yang dianggap usang atau ketinggalan terhadap perubahan masyarakat atau masyarakat yang telah mengalami perubahan.

3. Penemuan hukum oleh hakim yang merupakan karya hakim untuk memerankan hukum sebagai "a tool of social engineering". Jenis ini yang paling sedikit di antara keseluruhan putusan hakim.

Pada dasarnya dalam penemuan hukum dikenal adanya aliran progresif dan aliran konservatif. Aliran progresif berpendapat bahwa hukum dan peradilan merupakan alat untuk mencapai perubahan-perubahan sosial, sedangkan aliran konservatif berpendapat bahwa hukum dan peradilan itu hanyalah alat untuk mencegah kemerosotan moral dan nilai-nilai lain. ${ }^{30}$ Menurut Ahmad Rifa'i, dalam diri hakim diemban amanah agar peraturan perundang-undangan diterapkan secara benar dan adil, dan apabila penerapan peraturan perundang-undangan akan menimbulkan ketidak-adilan, maka hakim wajib berpihak pada keadilan (moral justice) dan mengenyampingkan hukum atau peraturan perundang-undangan (legal justice). Hukum yang baik adalah hukum yang sesuai dengan hukum yang hidup dalam masyarakat (the living law) yang tentunya sesuai pula atau merupakan pencerminan dari nilai-nilai yang berlaku dalam masyarakat (social justice). Keadilan yang dimaksudkan di sini, bukanlah keadilan prosedural (formil), akan

$29 \quad$ Ibid, hlm. 160.

$30 \quad$ Ibid, hlm. 158. 
tetapi keadilan subtantif (materiil), yang sesuai dengan hati nurani hakim. ${ }^{31}$

Selain berhubungan dengan dinamika politik legislasi pembuat undang-undang (positif legislator), dalam konteks tertentu pembentukan hukum oleh hakim (Mahkamah Agung dan badan peradilan di bawahnya) juga berinteraksi secara dinamis dengan pemegang kuasa negatif legislator yaitu Mahkamah Konstitusi. Pada asasnya putusan Mahkamah Konstitusi yang final dan mengikat secara umum (erga omnes) setara dengan undang-undang. Namun ternyata tidak serta merta dapat mengikat atau dilaksanakan oleh Mahkamah Agung. Ditinjau dari perspektif asas yang lain, hakim pada Mahkamah Agung dan peradilan di bawahnya bukanlah corong undang-undang, karenanya memiliki kewenangan melakukan penafsiran terhadap undang-undang (pun juga terhadap putusan Mahkamah Konstitusi) untuk diterapkan terhadap perkara yang ditanganinya. Apalagi dalam konteks law in concreto, para hakim pada Mahkamah Agung dan peradilan di bawahnyalah yang menerapkan dan mengkontekstualisasikan ketentuan peraturan perundang-undangan sesuai dengan kasus dan fakta perkara yang ditanganinya.

Misalnya dalam hal penerapan sifat melawan hukum materiil dalam tindak pidana korupsi yang notabene oleh putusan Mahkamah Konsitusi Nomor 003/PUU-IV/2006 tanggal 25 Juli 2006 tentang judicial review terhadap penjelasan Pasal 2 ayat (1) Undang-Undang No. 31 tahun 1999 jo. Undang Undang No. 20 tahun 2001 tentang Pemberantasan Tindak Pidana Korupsi memutuskan bahwa "Yang dimaksud dengan 'secara melawan hukum' dalam Pasal ini mencakup perbuatan melawan hukum dalam arti formil maupun dalam arti materiil, yakni meskipun perbuatan tersebut tidak diatur dalam peraturan perundang-undangan, namun apabila perbuatan tersebut dianggap tercela karena tidak sesuai dengan rasa keadilan atau norma-norma kehidupan sosial dalam masyarakat, maka perbuatan tersebut dapat dipidana" bertentangan dengan UndangUndang Dasar Negara Republik Indonesia Tahun 1945 dan dinyatakan tidak mempunyai kekuatan hukum mengikat. Artinya pengertian melawan hukum yang seharusnya dipergunakan didalam pembuktian tindak pidana korupsi adalah hanya terbatas kepada pengertian melawan hukum formil.

Meskipun Mahkamah Konstitusi berpandangan demikian, namun putusan Mahkamah Agung Nomor 996 K/Pid/2006 tanggal 16 Agustus 2006 atas nama terdakwa Hamdani Amin dan putusan Mahkamah Agung Nomor 1974 K/Pid/2006 tanggal 13 Oktober 2006 atas nama terdakwa Prof. Dr. Rusadi Kantaprawira SH, putusan Mahkamah Agung No. 1144/K-Pid/2006 tanggal 13 September 2007 dalam perkara ECW Neloe, putusan Mahkamah Agung No. 2065/K/Pid/2006 tanggal 21 Desember 2006 atas nama Drs. Kuncoro Hendartomo, dan putusan No. 207 K/Pid/2007 tanggal 28 februari 2007 atas nama Ir. Ishak, serta dalam putusan Pengadilan Negeri Jakarta Selatan No. 1280/Pid.B/2009/Pn.JKT.Sel atas nama Ir. Brahmantyo Irawan Kuhandoko dan Ir. Achmad Fachrie, ternyata pengadilan masih menerapkan unsur melawan hukum materiil.

31 Ahmad Rifai, Penemuan Hukum Oleh Hakim Dalam Perspektif Hukum Progresif(Jakarta: Sinar Grafika, 2011), hlm. 127-128. 
Adapun pertimbangannya yurisprudensi dan doktrin masih dipandang sebagai sumber hukum yang diikuti dalam praktek sebagai acuan oleh badan peradilan (Pengadilan Negeri, Pengadilan Tinggi dan Mahkamah Agung) dalam penanganan kasus konkrit yang dihadapinya, agar terbina konsistensi penerapannya dalam perkara-perkara tindak pidana korupsi, karena sudah sesuai dengan kesadaran hukum dalam masyarakat, kebutuhan hukum masyarakat, nilai-nilai hukum dan rasa keadilan yang hidup dalam masyarakat. ${ }^{32}$

Pada dasarnya Mahkamah Agung dan badan peradilan di bawahnya sudah sejak lama telah menerapkan "materiele wederrechtelijkeheid" dalam berbagai putusan perkara tindak pidana korupsi, baik dalam fungsinya negatf maupun positif seperti terlihat pada putusan No. $42 \mathrm{~K} /$ Kr/1965 tanggal 8 Januari 1966, putusan No. $81 \mathrm{~K} / \mathrm{Kr} / 1973$ tanggal 30 Maret 1977, putusan No. 275 K/Pid/1983 tanggal 15 Desember 1983, putusan No. $25 \mathrm{~K} / \mathrm{Pid} / 1983$ tanggal 29 Desember 1983, putusan No. 24 K/Pid/1984 tanggal 6 Juni 1985, dan putusan No. $241 \mathrm{~K} / \mathrm{Pid} / 1987$ tanggal 21 Januari 1989. ${ }^{33}$ Konsekuensi logis dimensi demikian membawa suatu polarisasi pemikiran bahwa Mahkamah Agung ingin menjatuhkan hukuman sesuai nuansa dan paradigma asas keadilan yang walaupun tidak diatur dalam undang-undang akan tetapi karena praktik di masyarakat dianggap sebagai sebuah perbuatan tercela, maka aspek demikian tidak dapat dibiarkan dan pelakunya harus dijatuhi hukuman sesuai norma yang hidup dalam masyarakat (living law) dengan tetap mempergunakan parameter asas keadilan. ${ }^{34}$

Berdasarkan penerapan sifat melawan hukum materiil dalam putusan-putusan yang diacu sebagai yurisprudensi tersebut kemudian diakomodir oleh DPR dalam rumusan penjelasan pasal 2 Undang-Undang No. 31 tahun 1999 jo. Undang Undang No. 20 tahun 2001 tentang Pemberantasan Tindak Pidana Korupsi yang selanjutnya dikemudian hari dibatalkan oleh Mahkamah Konstitusi. Dalam konteks ini tersimpul dinamika politik legislasi antara Mahkamah Agung melalui putusan pembentukan hukumnya di satu sisi dengan pembentuk undang-undang (DPR) yang secara positif merespon yurisprudensi dan Mahkamah Konstitusi selaku negatif legislator yang membatalkan hasil hubungan positif dari putusan Mahkamah Agung dan DPR tersebut. Kemudian pasca putusan Mahkamah Konstitusi, sebagian putusan Mahkamah Agung tidak mengindahkannya dengan tetap menerapkan sifat melawan hukum materiil dalam tindak pidana korupsi berdasarkan pada yurisprudensi tetap. Dalam konteks ini penerapan perbuatan melawan hukum materiil seolah terasa "hidup kembali"35 dan dihidupkan oleh Mahkamah Agung meskipun bertentangan dengan putusan Mahkamah Konstitusi.

Kondisi yang demikianlah membuat hubungan pembentukan hukum oleh hakim (Mahkamah Agung dan badan peradilan di

\footnotetext{
32 Marwan Effendy, Kapita Selekta Hukum Pidana: Perkembangan dan Isu-Isu Aktual dalam Kejahatan Finanasial dan Korupsi (Jakarta: Referensi, 2012), hlm.116-117.

33 Ibid, hlm. 115.

34 Lilik Mulyadi, "Perbuatan Melawan Hukum” dalam Tipikor pada Putusan MA, (Majalah Mahkamah Agung Nomor 3 Edisi September 2013), hlm. 68.

35 Ibid.
} 
bawahnya) dengan politik legislasi (dari kuasa negatif legislator) berlangsung secara dinamis dan berpengaruh terhadap penegakan hukum di Indonesia. Apakah masih menggunakan dan perlu diterapkan sifat melawan hukum materiil dalam penegakan hukum Tipikor ataukah tidak? Kebingungan dari aparat penegak hukum (Polisi, Jaksa dan Komisi Pemberantasan Korupsi) sudah pasti akan terjadi. Belum lagi polemik dan kontroversi di masyarakat. Bagi yang pro terhadap putusan Mahkamah Agung yang bersikukuh mempedomani yurisprudensi beralasan bahwa tindak pidana korupsi sudah ditetapkan sebagai ekstra ordinary karenanya penanganannya pun harus di luar kewajaran (khusus), salah satunya dengan penerapan sifat melawan hukum materiil. Sementara bagi yang kontra berpendapat bahwa sebagai bentuk ketaatan pada norma konstitusi yang telah memberikan mandat kepada Mahkamah Konstitusi dalam rangka memutuskan validitas dan konstitusionalitas norma undang-undang, maka dari itu Mahkamah Agung harus mentaati dan mengikuti setiap putusan Mahkamah Konstitusi sepahit apapun itu (tidak sesuai dengan perasaan keadilan masyarakat yang menghendaki progresivitas pemberantasan korupsi) berdasarkan asas res judikata pro veritate habetur.

Pada konteks ini tidak terhindarkan perbedaan penafsiran normatif dan sosiologis serta filosofis diantara Mahkamah Agung dan Mahkamah Konstitusi, karenanya para pakar hukum pun terbelah dalam memaknainya. Saldi Isra berpendapat bahwa apabila perbedaan penafsiran terhadap undangundang tersebut benar-benar terjadi, maka yang semestinya diikuti adalah penafsiran yang dilakukan oleh Mahkamah Konstitusi. Sebab, penafsiran Mahkamah Konstitusi didasarkan pada norma konstitusi. Dalam hal ini, sumber validitas penafsiran Mahkamah Konstitusi adalah konstitusi. Sementara sumber valitasi penafsiran Mahkamah Agung adalah undangundang itu sendiri. Mahkamah Agung sesuai kewenangan tidak dapat memasuki ranah penafsiran konstitusi. Sebab, Mahkamah Agung pun mesti tunduk pada penafsiran yang dilakukan Mahkamah Konstitusi terhadap UUD 1945 dalam menilai dan menafsirkan sebuah atau bagian undang-undang tertentu. ${ }^{36}$

Lebih lanjut Saldi Isra menjelaskan bahwa sebagaimana setiap peraturan perundangundangan dianggap mempunyai daya laku serta daya ikat bagi setiap orang atau semua pihak. Seiring dengan sifat keberlakuan undangundang, maka pada saat undang-undang atau bagian dari undang-undang tersebut dibatalkan melalui proses pengujian undang-undang, maka ketidakberlakukan norma tersebut juga berlaku umum. Ketidakberlakuan undangundang bukan hanya bagi Pemohon yang mengajukan pengujian undang-undang, juga bukan hanya bagi pembentuk undang-undang semata, melainkan berlaku untuk semua pihak. Karena itu, tidak ada alasan untuk menolak putusan Mahkamah Konstitusi yang telah menghilangkan keberlakuan sebuah norma di dalam undang-undang ${ }^{37}$ (termasuk alasan atas dasar yurisprudensi)

Saldi Isra, Titik Singgung Wewenang Mahkamah Agung dengan Mahkamah Konstitusi, (Makalah dalam Seminar "Titik Singgung Wewenang antara Mahkamah Agung dan Mahkamah Konstitusi", diadakah oleh Badan Litbang Diklat Hukum dan Peradilan Mahkamah Agung, Jakarta, 13 November 2014), hlm. 10.

$37 \quad$ Ibid, hlm. 9. 
Jika dimaknai bahwa putusan Mahkamah Konstitusi setara dengan keberlakuan undangundang sehingga berlaku mengikat umum, maka menurut Lilik Mulyadi bahwa dikaji dari perspektif kebijakan pidana hakim selaku pemegang kebijakan aplikatif harus menerapkan peraturan perundang-undangan. hakim tidaklah harus berarti menjadi penyambung lidah atau corong undang-undang (bousche de la loi/mouth of the laws) akan tetapi hakim harus dapat menerapkan sebagai filter dan mengimplementasikan peraturan tersebut yang masih bersifat abstrak terhadap kasus konkrit. Konsekuensi logis dimensi demikian hakim dihadapkan kepada pilihan keadilan, kepastian dan kemanfaatan. Di satu sisi perbuatan korupsi secara formal (perbuatan melawan hukum formal) tidak ada, akan tetapi di sisi lainnya secara materiil (perbuatan melawan hukum materril) ada maka hakim sebagai kebijakan aplikasi harus menggali, memahami dan menghayati norma-norma hukum yang hidup di dalam masyarakat. Apabila dijabarkan lebih jauh paradigma konteks di atas dikarenakan hakim hidup di masyarakat, menggali dan menetapkan hukum untuk masyarakat, peraturan dibuat untuk suatu masyarakat dan juga tentu harus menjatuhkan hukuman sesuai dengan dimensi keadilan kepada masyakarat pendukungnya di mana hukum itu hidup (living law). Dalam paradigma modern sekarang dapat disebutkan dengan paradigma bahwa, "hakim tidak hidup dalam menara gading". 38

Adanya polemik tersebut memang dilematis, mengingat doktrin dan yurisprudensi memang bukan domain Mahkamah Konstitusi untuk mengujinya, tetapi jika ketentuan undangundang tidak diikuti oleh penegak hukum dan Mahkamah Agung sendiri yang mengawalinya, maka doktrin dan yurisprudensi tersebut akan tetap diikuti oleh pengadilan di bawahnya. ${ }^{39}$ Pada asasnya perbedaan pandangan tentang kedudukan pembentukan hukum oleh hakim terhadap eksistensi yurisprudensi di satu pihak dan undang-undang (putusan Mahkamah Konstitusi yang setara dengan undang-undang) di pihak lain didasarkan juga atas masalah eksistensi dan penerapan sumber hukum formil. Menurut Sudikno Mertokusumo, sumber utama penemuan hukum adalah peraturan perundangundangan, kemudian hukum kebiasaan, yurisprudensi, perjanjian internasional barulah doktrin. Jadi terdapat hierarki atau keseradaan dalam sumber hukum, ada tingkatan-tingkatan. Oleh karena itu, kalau terjadi konflik dua sumber, maka sumber hukum yang tertinggi akan melumpuhkan sumber hukum yang lebih rendah. ${ }^{40}$

Artinya, jika mengikuti pendapat Sudikno Mertokusumo di atas, maka putusan Mahkamah Agung yang tidak mengindahkan putusan Mahkamah Konstitusi yang notabene setara dengan undang-undang tersebut dengan mendahulukan atau mendasarkan yurisprudensi adalah tidak benar. Secara konstruksi sumber hukum formil, dengan kedudukan yurisprundensi yang ditempatkan nomor urut ketiga maka memberika sebuah konsekuensi bahwa sepanjang telah diatur dalam undang-undang (a quo putusan Mahkamah Konstitusi) maka yurisprudensi tidak dapat menyimpangkannya. Kecuali jika

38 Lilik Mulyadi, "Perbuatan Melawan Hukum" ...Op Cit, hlm. 68.

39 Marwan Effendy, Op Cit, hlm. 117.

40 Sudikno Mertokusumo, Penemuan Hukum, (Yogyakarta: Universitas Atmajaya Yogyakarta, 2010), hlm. 63-64. 
tidak terdapat dalam undang-undang maka yurisprudensi dapat diterapkan sepajang hukum kebiasaan terlebih dahulu yang diutamakan (karena secara berurutan kebiasaan di urutan nomor 2 dan di atas yursiprudensi) sebelum penggunaan yurisprudensi.

Berbeda halnya dengan pendapat Sudikno Mertokusumo yang secara struktural menempatkan sumber hukum formil dalam sebuah hirarki hingga secara positivis menempatkan undang-undang di atas pembentukan hukum hakim, Satjipto Rahardjo menjelaskan bahwa ketentuanyang menentukan hakim sebagai penegak hukum dan keadilan wajib menggali, mengikuti dan memahami nilai-nilai hukum yang hidup di masyarakat itu, bisa ditafsirkan sebagai pemberian kekuasaan kepada pengadilan untuk menentukan sendiri apa yang menurut pendapatnya layak diterima sebagai hukum di negeri ini. Konsekuensi penerimaan terhadap tafsiran tersebut adalah pengadilan bisa menyimpang dari ketentuan peraturan perundang-undangan yang berlaku. Apabila peranan pengadilan tersebut dapat diterima, maka sumbangan lembaga hukum ini terhadap perubahan sosial yang terjadi di negeri ini akan besar sekali. Pendapat ini didasarkan kepada keadaan yang sudah menjadi klasik, yaitu pembuatan undang-undang itu ditakdirkan untuk tertinggal di belakang, apalagi masyarakat yang bersangkutan sedang mengalami perubahan sosial yang besar seperti halnya Indonesia. ${ }^{41}$

Berkaitan dengan pendapat Satjipto Rahardjo di atas maka tidak berlebihan kiranya jika para hakim didaulat sebagai aktor pembaru hukum. Dalam konteks ini dapat dimungkinkan Hakim Mahkamah Agung dan badan peradilan di bawahnya melakukan interpretasi terhadap putusan Mahkamah Konstitusi yang notabene setara dengan undang-undang (negatif legislator), bilamana perkembangan dan rasa keadilan masyarakat mengalami perubahan. Sebagai bagian dari hukum, putusan Mahkamah Konstitusi yang terkait dengan cara pandang para Hakimnya melekat erat dengan konteks suatu keadaan, kedudukan dan kekinian serta budaya masyarakat. Oleh karenanya tidak lahir dari kehendak bebas (arbitary act of a legislator), tetapi dibangun dan dapat ditemukan didalam jiwa masyarakat. Budaya dan kebiasaan merupakan produk dari kesadaran sejarah masyarakatnya. Kesadaran sejarah bukan sesuatu yang statis, tetapi senantiasa berkembang seiring dengan perubahan sosial dan munculnya pemikiran-pemikiran baru. ${ }^{42}$ Sesaat ketika undang-undang atau putusan Mahkamah Konstitusi ditetapkan, saat itulah menjadi "teks" yang keberadaannya dalam perkembangan masyarakat berikutnya akan mengalami dinamika. Karenanya di masa yang akan datang dimungkinkan hakim menjelaskan atau mengisinya bilamana terdapat hal yang kurang jelas atau terdapat kekosongan hukum dengan melakukan kontekstualisasi penerapan undang-undang atau putusan Mahkamah Konstitusi tersebut sehingga sesuai dengan nilai dan rasa keadilan serta perkembangan masyarakat. 


\section{Penutup}

Pasal 24 UUD 1945 menyatakan bahwa "Kekuasaan Kehakiman merupakan kekuasaan yang merdeka untuk menyelenggarakan peradilan guna menegakkan hukum dan keadilan". Termasuk dalam kategori kemerdekaan yang dimaksudkan adalah kemerdekaan dalam hal memaknai nilainilai hukum dan rasa keadilan di masyarakat, sehingga hakim Indonesia tidak mutlak terikat dengan undang-undang (bukan corong undangundang). Sebagaimana hakikat undang-undang yang selalu tertinggal dengan perkembangan masyarakat, maka kewenangan penemuan hukum dalam pelaksanaan kekuasaan kehakiman merupakan keniscayaan. Bahkan dalam konteks tertentu hakim didorong untuk melakukan pembentukan hukum baru yang berfungsi sebagai a tool of social engineering. Jika pembentukan hukum oleh hakim diikuti secara konstan oleh hakim lain maka dapat dijadikan sebagai sumber hukum formil dalam sistem hukum nasional (yurisprudensi).

Tidak sedikit yurisprudensi yang telah menimbulkan berbagai perubahan besar dalam praktek penegakan dan pengembangan hukum sehingga menginspirasi pembaruan hukum dalam politik legislasi (DPR). Namun tidak semua yurisprudensi berpengaruh secara positif dan diakomodasi dalam pembaruan undang-undang oleh DPR. Sebagai institusi politik, DPR secara substantif tidak "imun" terhadap tawar-menawar kepentingan internal maupun eksternal anggotanya, sehingga konsensusnya selalu dinamis, baik dalam konteks fungsional, struktural maupun kultural. Selain itu dalam konteks politik legislasi lainnya, hubungan yurisprudensi dengan Negatif Legislator (putusan Mahkamah Konstitusi) pun tidak selalu statis. Putusan Mahkamah
Konstitusi yang bersifat final, mengikat umum (erga omnes) dan setara dengan undangundang, tidak serta merta dilaksanakan dan diikuti oleh Mahkamah Agung dengan alasan dasar mempedomani yurisprudensi atau pertimbangan membentuk tafsir hukum yang baru. Selayaknya undang-undang, putusan Mahkamah Konstitusi ditafsirkan oleh hakim untuk dikontekstualisasi dengan perkembangan nilai hukum dan rasa keadilan masyarakat sehingga ada kalanya berbeda secara tekstual dengan yang dikehendaki Perumus. Dalam konteks ini pembentukan hukum oleh hakim diakui eksistensinya dalam dinamika politik legislasi, baik yang bersifat positif maupun negatif.

\section{Daftar Pustaka}

\section{Buku}

Ali, Achmad, Menguak Tabir Hukum (Bogor: Ghalia Indonesia, 2011)

Ansyahrul, Pemuliaan Peradilan: dari Dimensi Integritas Hakim, Pengawasan, dan Hukum Acara (Jakarta: Mahkamah Agung, 2011)

Effendy, Marwan, Kapita Selekta Hukum Pidana: Perkembangan dan Isu-Isu Aktual dalam Kejahatan Finanasial dan Korupsi (Jakarta: Referensi, 2012)

Hoesein, Zainal Arifin, Kekuasaan Kehakiman di Indonesia (Yogyakarta: Imperium, 2013)

Idris, dkk. (Ed), Penemuan Hukum Nasional dan Internasional (dalam rangka Purna Bakti Prof. Dr.Yudha Bhakti,SH.,MH) (Bandung: Fikahati Aneska, 2012)

Kamil, Ahmad dan M. Fauzan, Kaidah-Kaidah Hukum Yurisprudensi (Jakarta: Kencana, 2008)

Kamil, Ahmad, Filsafat Kebebasan Hakim (Jakarta: Kencana Prenada Media, 2012)

Lubis, Todung Mulya, dan Alexander Lay, Kontroversi Hukuman Mati: Perbedaan Pendapat Hakim Konstitusi (Jakarta: Kompas, 2009)

Mertokusumo, Sudikno, Penemuan Hukum (Yogyakarta: Universitas Atmajaya Yogyakarta, 2010) 
Mertokusumo, Sudikno, Penemuan Hukum: Sebuah Pengantar (Yogyakarta: Cahaya Atma Pustaka, 2014)

Moerad, Pontang, Pembentukan Hukum melalui Putusan Pengadilan dalam Perkara Pidana (Bandung: Alumni, 2005)

Mulyadi, Lilik, Bunga Rampai Hukum Pidana: Perspektif Teoritis dan Praktik (Bandung, Alumni, 2012)

Mulyadi, Lilik, Hukum Acara Pidana Indonesia: Suatu Tinjauan Khusus terhadap Surat Dakwaan, Eksepsi dan Putusan Peradilan (Bandung: Citra Aditya Bakti, 2012)

Pangaribuan, Luhut M.P., Lay Judges \& Hakim Ad Hoc: Suatu Studi Teoritis mengenai Sistem Peradilan Pidana Indonesia (Jakarta: Fakultas Hukum Pasca Sarjana Universitas Indonesia dan Papas Sinar Sisanti, 2009)

Praja, Juhaya S., Teori Hukum dan Aplikasinya (Bandung: Pustaka Setia, 2011)

Qamar, Nurul, Percikan Pemikiran Tentang Hukum (Makassar: Pustaka Refleksi, 2011)

Rahardjo, Satjipto, Hukum dan Perubahan Sosial: Suatu Tinjauan Teoritis serta PengalamanPengalaman di Indonesia (Yogyakarta: Genta Publishing, 2009)

Rahardjo, Satjipto, Penegakan Hukum Progresif (Jakarta: Kompas, 2010)

Rifai, Ahmad, Penemuan Hukum Oleh Hakim Dalam Perspektif Hukum Progresif (Jakarta: Sinar Grafika, 2011)
Sutiyoso, Bambang, Metode Penemuan Hukum: Upaya Mewujudkan Hukum yang Pasti dan Berkeadilan (Yogyakarta: UII Press, 2012)

Yesmil Anwar dan Adang, Pembaruan Hukum Pidana (Jakarta: Grassindo, 2008)

Yuti Witanto, Darmoko dan Arya Putra Negara Kutawaringin, Diskresi Hakim: Sebuah Instrumen Menegakkan Keadilan Substantif dalam PerkaraPerkara Pidana. (Bandung: Alfabeta, 2013)

\section{Makalah/Artikel/Prosiding/Hasil Penelitian}

Isra, Saldi, Titik Singgung Wewenang Mahkamah Agung dengan Mahkamah Konstitusi, (Makalah dalam Seminar "Titik Singgung Wewenang antara Mahkamah Agung dan Mahkamah Konstitusi", diadakan oleh Badan Litbang Diklat Hukum dan Peradilan Mahkamah Agung, Jakarta, 13 November 2014)

Malik, Telaah Makna Hukum Putusan Mahkamah Konstitusi yang Final dan Mengikat, Jurnal Konstitusi Volume 6 Nomor 1 (2009)

Mulyadi, Lilik, "Perbuatan Melawan Hukum" dalam Tipikor pada Putusan MA, (Majalah Mahkamah Agung Nomor 3 Edisi September 2013)

\section{Peraturan}

Undang-Undang Nomor 48 Tahun 2009 tentang Kekuasaan Kehakiman 